\title{
STUDI KASUS YAYASAN X: HUBUNGAN ANTARA HASIL TES SELEKSI KARYAWAN BARU DENGAN HASIL KINERJA KARYAWAN SETELAH BEKERJA MIN. 12 BULAN
}

\author{
Bernadetta Junita Santosa \\ Jurusan Psikologi, Fakultas Psikologi, Bina Nusantara University \\ Jln. Kemanggisan Ilir III No 45, Kemanggisan, Palmerah, Jakarta Barat 11480 \\ detta@binus.edu
}

\begin{abstract}
Case study in Institution $X$ is purposed to see connection between new employee selection result as psychological test and employee interview in KPI, a competencies and total score after working at least 1 year. This case study related to how important the connection between the two variables, especially related to validity from existing selection test. This research uses quantitative method (statistical calculation) with gathering main data in Institution X, with descriptive and correlation method. Subjects are 160 employees selected on 2008 and have been through performance evaluation on 2009, in different positions and levels. The general result shows that there is no significant connection between test result and employees' performance result in KPI, competencies and total score. Suggestion for this study is by giving test tools renovation for selecting new employees.
\end{abstract}

Keywords: recruitment and selection, psychological test, interview, performance management

\begin{abstract}
ABSTRAK
Studi kasus pada Yayasan X bertujuan untuk melihat hubungan antara hasil seleksi karyawan baru yang berupa hasil gabungan tes psikologi dan wawancara dengan hasil kinerja karyawan dalam bentuk nilai KPI, nilai kompetensi dan nilai total score setelah bekerja minimum 1 tahun. Studi kasus ini dilakukan atas dasar pentingnya melihat hubungan antara kedua variabel tersebut, terutama yang berhubungan dengan validitas dari tes yang digunakan untuk seleksi itu sendiri. Penelitian dilakukan dengan menggunakan metode kuantitatif (perhitungan statistika) dengan pengambilan data primer yang sudah ada di Yayasan X, dengan metode deskriptif dan korelasi. Subyek sebanyak 160 orang karyawan yang diseleksi pada 2008 dan sudah mengalami evaluasi kinerja pada tahun 2009, pada posisi yang berbeda dan level yang berbeda. Hasilnya secara umum memperlihatkan tidak adanya hubungan yang signifikan antara hasil tes dengan hasil kinerja karyawan yang berupa nilai KPI, nilai kompetensi dan nilai total score. Saran-saran diajukan untuk memberikan sumbangan bagi perbaikan alat tes yang akan digunakan untuk menyeleksi karyawan baru.
\end{abstract}

Kata kunci: rekrutmen dan seleksi, tes psikologi, wawancara, manajemen kinerja 


\section{PENDAHULUAN}

Yayasan $\mathrm{X}$ adalah salah satu institusi pendidikan yang terkemuka di Indonesia, yang menyediakan jenjang pendidikan dari TK sampai dengan S3 (akan mulai beroperasi di tahun 2011) dan juga memiliki beberapa tempat kursus. Sebagai institusi pendidikan, Yayasan $\mathrm{X}$ sangat memperhatikan sumber daya manusianya, yang terdiri dari staf akademis, seperti guru, dosen, asisten laboratorium dan staf administrasi non akademis. Saat ini Yayasan X memiliki kurang lebih 1635 orang karyawan, dengan turn over rate sekitar 7\% per tahun.

Proses rekrutmen dan seleksi karyawan baru di suatu perusahaan atau organisasi merupakan salah satu bagian penting dalam pengelolaan sumber daya manusia dan proses perencanaan di perusahaan atau organisasi tersebut. Hal ini dikarenakan proses recruitment dan seleksi berhubungan dengan bagian lain dalam pengelolaan sumber daya manusia, seperti desain pekerjaan, training dan development, penilaian kinerja (performance), sistem rewards, karir dan succession planning, promosi dan transfer (Compton, Morrissey \& Nankervis, 2002). Dalam pengelolaan sumber daya manusia itu sendiri, karyawan merupakan sumber atau asset yang penting bagi perusahaan atau organisasi itu, karena karyawan akan memberikan suatu kontribusi dan produktivitasnya bagi keuntungan dan kelangsungan perusahaan atau organisasi. Oleh karena itu, proses recruitment dan seleksi, terutama bagi karyawan baru diharapkan dapat membantu perusahaan atau organisasi menempatkan sumber daya manusianya ditempat yang tepat dan diwaktu yang tepat (the right man in the right place and right time). Hal ini berhubungan dengan salah satu fungsi recruitment yaitu memastikan bahwa perusahaan atau organisasi selalu memiliki staff yang tepat sepanjang waktu. Oleh karena itu, tujuan dari recruitment adalah menarik orang yang tepat untuk melamar ke posisi tersebut dengan cara membuat mereka sadar bahwa perusahaan atau organisasi sedang membutuhkan kandidat untuk posisi dan posisi tersebut terbuka di perusahaan atau organisasi tersebut (Compton, Morrissey \& Nankervis, 2002).

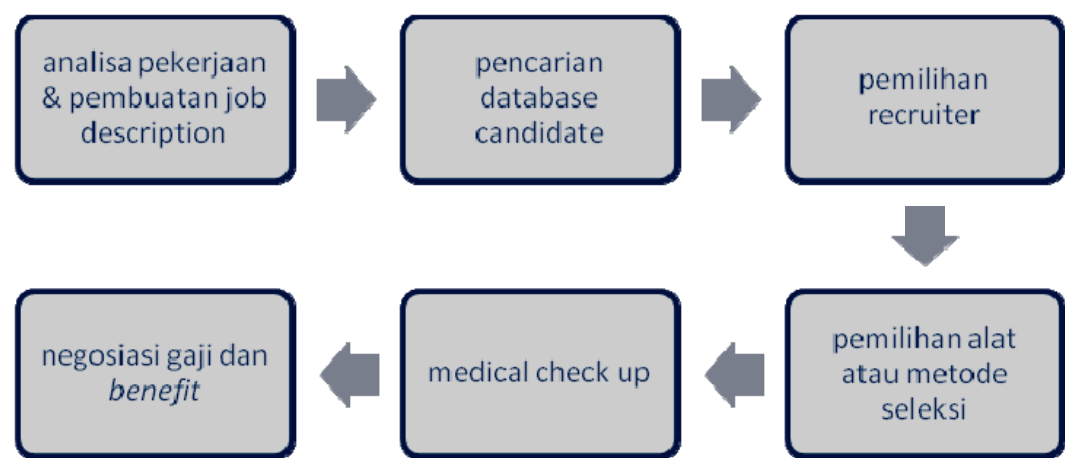

Gambar 1 Proses umum rekrutmen dan seleksi

Secara umum, proses rekrutmen dan seleksi meliputi beberapa proses, yaitu analisa pekerjaan dan pembuatan job description, pencarian database kandidat untuk posisi tersebut, karakteristik dari recruiter (agencies, internal, outsourcing dan lain-lain), alat dan teknik yang digunakan dalam seleksi, medical checkup dan proses negosiasi gaji dan benefit (rewards).

Dalam pengembangan dari proses rekrutmen secara umum pada Gambar 1, dalam melakukan perekrutan karyawan baru, Yayasan X menggunakan metode seperti yang terlihat dalam Gambar 2 . Adapun dalam proses seleksi tersebut Yayasan $\mathrm{X}$ melakukan sendiri proses seleksinya dengan melibatkan para manager dan team leader (User) di dalam prosesnya. 


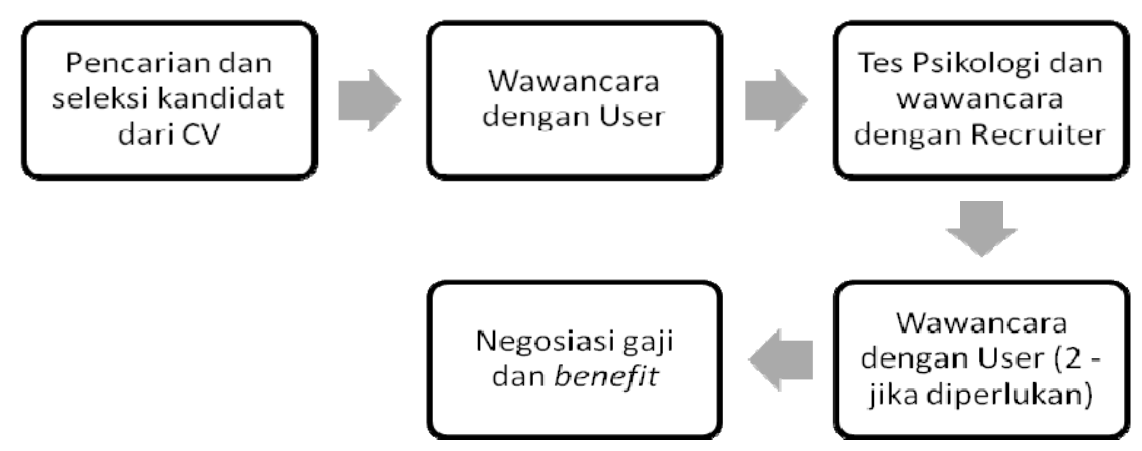

Diagram 2 Proses Seleksi di Yayasan X

Salah satu yang paling penting disini adalah alat dan metode yang digunakan dalam seleksi karena menentukan apakah kandidat tersebut termasuk dalam kategori yang dapat dipertimbangkan atau tidak dipertimbangkan untuk posisi tersebut (Schultz \& Schultz, 2006). Alat dan teknik yang digunakan dalam seleksi bisa bermacam-macam, mulai dari application blanks, interview, surat rekomendasi, assessment centers dan tes psikologi. Biasanya dalam perusahaan atau organisasi tidak menggunakan satu alat atau teknik, tetapi bisa merupakan gabungan dari beberapa metode (Schultz \& Schultz, 2006). Namun, perlu diperhatikan juga bahwa proses yang paling penting dalam proses seleksi adalah melakukan tes apakah prosedur seleksi yang digunakan oleh perusahaan atau organisasi tersebut telah sukses mengidentifikasi pekerja atau karyawan yang nantinya dapat memberikan kinerja (performance) yang baik bagi perusahaan atau organisasi, terutama di dalam posisi atau pekerjaannya tersebut. Salah satu caranya adalah departemen sumber daya manusia di perusahaan atau organisasi harus mendata perkembangan kinerja karyawan dalam posisi tersebut setelah periode waktu tertentu. Saat ini, seperti terlihat pada Gambar 2, Yayasan X menggunakan tehnik wawancara dan tes psikologi untuk melakukan seleksi. Untuk kedua tehnik tersebut, Yayasan $\mathrm{X}$ berusaha untuk menemukan intelligensi, kepribadian dan gaya kerja dari individu, terutama dalam melakukan pekerjaannya.

Wawancara adalah perbincangan yang terjadi antara dua atau lebih orang (disebut sebagai interviewer dan interviewee) dimana ada pertanyaan tertentu yang diajukan oleh interviewer untuk memperoleh informasi dari interviewee (Steward \& Cash, dalam Hamilton, 2008). Wawancana tidak dapat memberikan keakuratan dalam segala hal ataupun memprediksi kesuksesan seseorang, tetapi wawancara dapat memberikan informasi yang tidak didapatkan oleh alat atau metode yang lain, misalnya motivasi, kecocokan individu dengan pekerjaannya, keterampilan berkomunikasi dan nilainilai yang dianut seseorang dalam bekerja. Wawancara di Yayasan X dilakukan dua kali, oleh user dan oleh recruiter; dengan perbedaan user lebih memfokuskan pada keterampilan yang dibutuhkan dalam pekerjaan tersebut, sedangkan recruiter lebih memfokuskan pada tingkah laku yang dimiliki dan akan dilakukan oleh individu dalam melakukan pekerjaannya. Tes psikologi, yaitu pengukuran yang objektif dan terstandar dari contoh tingkah laku individu (Anastasi \& Urbina, 1997). Tingkat diagnostik dan peramalan (predictive) dari suatu alat tes psikologis tergantung pada derajat dimana tes tersebut menjadi indikasi dari area tingkah laku yang ingin dicari. Tes psikologi juga memprediksi perilaku berdasarkan contoh tingkah laku yang terjadi pada saat ini. Ada berbagai jenis tes psikologi, salah satunya adalah (1) intelligence test yaitu tes yang mengukurmintelengsi seseorang termasuk didalamnya adalah kemampuan untuk memahami keadaan disekitar kita, kita berfungsi dengan baik dan mengaplikasikan pengetahuan untuk meningkatkan kualitas hidup. (2) neuropsychological test yaitu test yeng mengukur kemampuan kognitif kita dalam hal kemampuan berpikir, berbicara, memberikan pemahaman, dan sebagainya, jika ada penyimpangan maka disebut sebagai brain damage. (3) Occupational test, yaitu tes yang berusaha untuk menemukan minat individu dengan minat yang akan ia jalanin, terutama dalam hal karir. Dan yang terakhir adalah personality tests yaitu tes yang berusaha untuk mengikut tipe kepribadian dasar individu. 
Di dalam tes psikologi yang berhubungan dengan pekerjaan, biasanya jenis tes yang digunakan adalah intelligence tests, occupational tests dan personality test; hal ini dikarenakan perusahaan/organisasi ingin melihat bagaimana orang itu akan berfungsi dalam pekerjaannya, apakah minat orang tersebut memang sesuai dengan pekerjaan yang akan dilakukannya dan bagaimana kepribadian dari orang tersebut, terutama dalam hal motivasi, hasrat berprestasi, kemampuan bersosialisasi, bekerja dalam kelompok dan macam-macam gaya kerja lainnya yang dituntut oleh perusahaan/organisasi tersebut. Hasil dari tes psikologi dan wawancara biasanya berbentuk kualitatif, bukan kuantitatif karena memberikan deskripsi mengenai keadaan individu tersebut pada masa kini, yang dapat digunakan untuk melakukan prediksi terhadap kemungkinan tingkah lakunya di masa mendatang.

Selain itu, dalam menentukan alat atau metode yang digunakan, perlu diperhatikan juga mengenai validitas dari suatu alat test. Validitas adalah derajat yang menyatakan suatu tes mengukur apa yang seharusnya diukur. Validitas suatu tes tidak begitu saja melekat pada tes itu sendiri, tetapi tergantung penggunaan dan subyeknya (Sukadji, 2000). Validitas dipecah lagi menjadi berbagai jenis yaitu (a) validitas isi, yaitu seberapa besar derajat tes mengukur representasi isi yang dikehendaki untuk diukur. Validitas aitem berkaitan dengan apakah aitem mewakili pengukuran dalam area isi sasaran yang diukur, dan validitas sampling adalah seberapa baik sampel isi tes mewakili keseluruhan isi sasaran yang diukur. Biasanya dinilai dengan menggunakan pertimbangan pakar. (b) Validitas konstruk/teoretis adalah seberapa besar derajat tes mengukur konstruk hipotesis yang dikehendaki untuk diukur. Konstruk adalah perangai yang tidak dapat diamati, yang menjelaskan perilaku. Menguji validitas konstruk mencakup uji hipotesis yang dideduksi dari suatu teori yang mengajukan konstruk tersebut. (c) Validitas Konkruen yang menunjukkan seberapa besar derajat skor tes berkorelasi dengan skor yang diperoleh dari tes lain yang sudah mantap, bila disajikan pada saat yang sama, atau dibandingkan dengan kriteria lain yang valid yang diperoleh pada saat yang sama; dan (d) Validitas Prediktif adalah seberapa besar derajat tes berhasil memprediksi kesuksesan seseorang pada situasi yang akan datang. Validitas prediktif ditentukan dengan mengungkap hubungan antara skor tes dengan hasil tes atau ukuran lain kesuksesan dalam satu situasi sasaran.

Situasi yang akan datang dalam pekerjaan dapat diukur melalui kinerjanya. Performance management atau manajemen kinerja dalam suatu perusahaan dapat diartikan sebagai mendapatkan hasil yang lebih baik dari organisasi, kelompok (team) dan individu dengan cara memahami dan mengatur kinerja dalam framework yang terdiri dari rencana, tujuan, standard, attribute atau competence requirements yang telah disepakati bersama (Armstrong, 1995). Dalam hal ini, framework tersebut telah disetujui bersama antara manager dengan individu, sehingga keduanya memiliki pengertian yang sama dalam hal hasil dan tujuan yang akan dicapai. Selain itu, manajemen kinerja bukan saja suatu sistem dengan formulir-formulir yang harus diisi dan prosedur, tetapi lebih menekankan pada aktivitas atau action sehari-hari yang individu tersebut lakukan untuk mencapai hasil dan memperbaiki/improvement hasil tersebut pada dirinya sendiri maupun orang lain. Untuk memperbaiki/improvement dari hasil tersebut, individu perlu memiliki pemahaman yang sama mengenai kinerja yang diharapkan, yang dalam hal ini adalah kinerja yang tinggi, kompetensi yang dibutuhkan dan apa yang akan mereka capai. Manajemen kinerja memfokuskan diri pada 3 hal, yaitu bagaimana manajer dan team leader bekerja secara efektif dengan orang-orang disekitar mereka, terutama para bawahan mereka, bagaimana para individu bekerja dengan manager dan kelompok kerja mereka; dan yang terakhir bagaimana para individu dapat dikembangkan dalam hal pengetahuan, keterampilan, keahlian mereka (attributes), kompetensi dan kinerja itu sendiri. Terakhir, yang paling penting dalam manajemen kinerja adalah tentang pencapaian prestasi akan kesuksesan dari individu tersebut karena mereka telah menggunakan kemampuan mereka, menyadari potensi-potensi mereka dan memaksimalkan kontribusi mereka demi perusahaan/organisasi mereka. 
Jika dilihat pada Gambar 3 manajemen kinerja adalah usaha yang terintegrasi. Hal ini menunjukan bahwa managemen kinerja berhubungan langsung dengan motivasi dalam mencapai tujuan, reinforcement dan harapan dari individu. Menurut Latham \& Locke (dalam Armstrong, 1995), tujuan yang baik adalah yang spesifik, menantang tetapi tetap dapat diraih, dilihat adil dan masuk akal, akan lebih baik jika individu terlibat dalam pembentukan dan penentuan tujuan tersebut, ada feedback yang memastikan individu mendapatkan kepuasan dan kebanggaan dalam pengalamannya mencapai tujuan tersebut dan feedback ini dapat digunakan dalam memperoleh komitmen untuk mencapai tujuan yang lebih tinggi lagi. Sedangkan menurut teori reinforcement, kesuksesan dalam mencapai tujuan dan rewards adalah hadiah positif dan akan membuat individu berkeinginan meraih kesuksesan lagi di masa mendatang. Harapan dari individu menurut Vroom (dalam Armstrong, 1995) dalam meningkatkan motivasi untuk berprestasi dan meraih tujuan, individu harus mampu mengubah tingkah laku, merasa percaya bahwa mengubah tingkah laku akan memberikan rewards bagi mereka dan memberikan nilai pada rewards tersebut bahwa rewards tersebut didapat karena mereka melakukan perubahan perilaku.

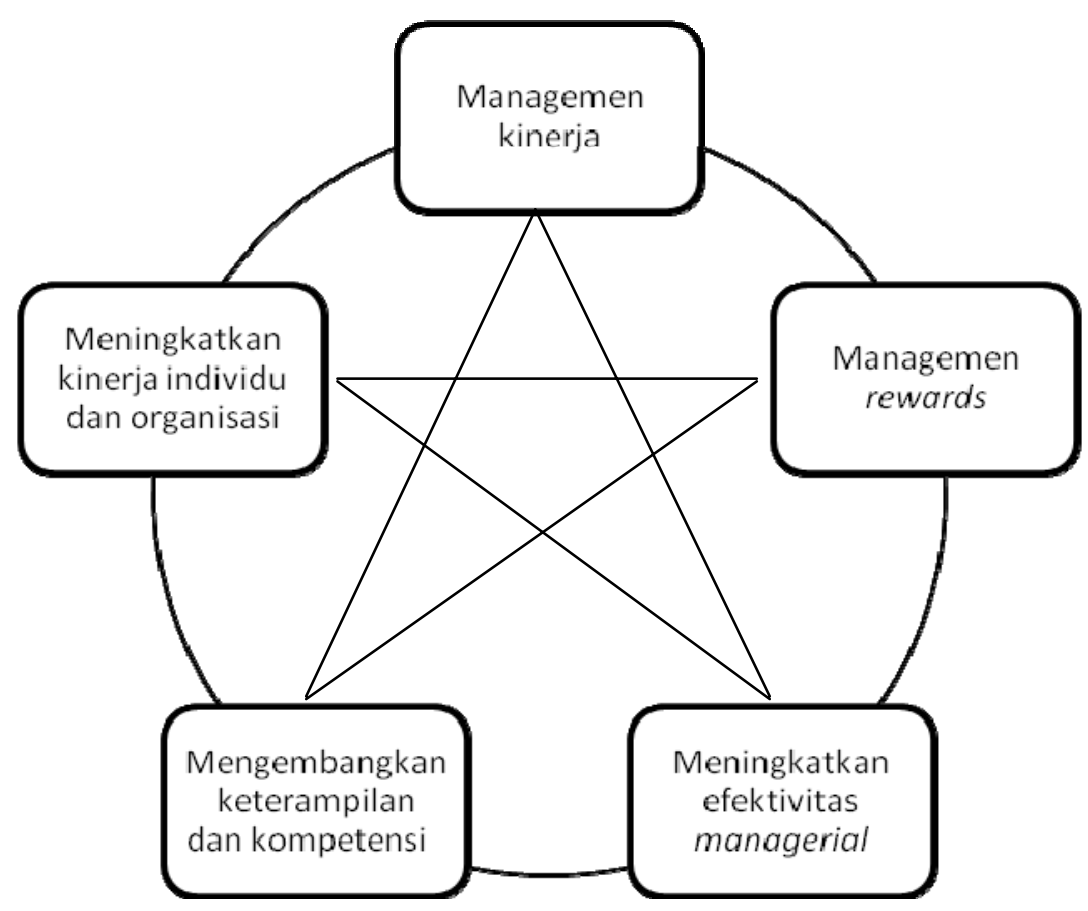

Gambar 3 Managemen Kinerja sebagai usaha yang terintegrasi

Di Yayasan X, managemen kinerja dinilai melalui 2 cara, yaitu melalui target kerja yang diberikan atau disebut dengan KPI (Key Performance Indicator) dan kompetensi; dan sebagai hasil akhirnya akan dihitung dengan menggunakan total skor, yaitu $70 \%$ nilai KPI dan $30 \%$ nilai kompetensi. KPI adalah salah satu tehnik yang digunakan untuk mengukur kinerja pada saat ini tingkat yang telah disepakati bersama, disertai dengan gambaran aktivitas yang akan dilakukan untuk mencapai tujuan tersebut. Seperti pada managemen kinerja, KPI akan tergantung pada visi dan tujuan jangka panjang dari Yayasan X. Sedangkan kompetensi adalah kriteria standard dari seorang individu untuk dapat melakukan pekerjaanya dengan baik dalam posisi/pekerjaan tertentu. Kompetensi adalah gabungan antara pengetahuan (knowledge), keterampilan (skills) dan tingkah laku (behavior). Yayasan $\mathrm{X}$ memiliki 11 kompetensi umum dan 2 kompetensi yang berhubungan dengan keterampilan. Masingmasing kompetensi memiliki 4 level, yaitu level 1 beginner, level 2 individual contributor, level 3 mentor/coach, dan level 4 role model. Keduanya, KPI dan kompetensi dinilai dengan menggunakan skor $1-6$. 
Tulisan ini memfokuskan studi kasus di Yayasan X dengan melihat hubungan antara hasil gabungan tes psikologi dan wawancara calon karyawan dengan hasil kinerjanya pada posisi tertentu setelah masa kerja minimum satu tahun di Yayasan X. Diharapkan dengan membandingkan hasil gabungan tes psikologi dan wawancata dengan hasil kinerja, kita dapat melihat korelasinya, sehingga dapat melihat apakah tehnik seleksi yang digunakan oleh Yayasan X dapat memprediksi apakah kandidat-kandidat tersebut dapat menjadi karyawan yang efektif dan baik bagi Yayasan tersebut. Hal ini belum pernah dilakukan sebelumnya di Yayasan X, sehingga hal ini merupakan hal yang baru dan dapat menjadi masukan yang bermanfaat.

\section{METODE PENELITIAN}

Penelitian ini merupakan penelitian non eksperimental yang bersifat studi kasus pada Yayasan X, di mana dapat diartikan sebagai Mempelajari secara intensif latar belakang serta interaksi lingkungan dari unit yang menjadi subjek; tujuannya memberikan gambaran secara detail tentang latar belakang, sifat, karakteristik yang khas dari kasus, yang kemudian dijadikan suatu hal yang bersifat umum. Hasilnya merupakan suatu generalisasi dari pola-pola kasus yang tipikal. Ruang lingkupnya bisa bagian/ segmen, atau keseluruhan siklus/ aspek. Penelitian ini lebih ditekankan kepada pengkajian variabel yang cukup banyak pada jumlah unit yang kecil. Metode yang digunakan adalah metode kuantatif dimana memakai suatu pengukuran yang terstandardisasi sehingga pandangan dan pengalaman subyek penelitian dapat dimasukkan ke dalam kategori-kategori yang telah ditentukan dan akan diukur (Patton, 1990). Menurut Shaughnessy \& Zechmeister (1997), penelitian kuantitatif adalah penelitian dengan hasil yang berasal dari analisis dan kesimpulan statistik. Salah satu bentuknya adalah analisis kuantitatif adalah dengan menggunakan statistical inference, yaitu tehnik yang digunakan untuk mengambil kesimpulan dan membuat generalisasi dari kelompok kecil ke kelompok yang lebih besar populasinya (Roscoe, 1969). Pengukuran yang dilakukan menggunakan SPSS 14.0 dengan korelasi Pearson Product Moment - Bivariat.

Korelasi Pearson Product Moment - bivariat, yaitu korelasi antara satu variable bebas dan satu variable tergantung. Korelasi Pearson digunakan untuk mengetahui ada dan tidaknya hubungan dua variable, yaitu variable bebas dan variabel tergantung yang berskala interval atau scale (Sarwono, 2006). Angka korelasi berkisar antara 0 sampai dengan 1, dengan ketentuan jika angka mendekati satu maka hubungan kedua variabel semakin kuat. Jika angka korelasi mendekati 0 maka hubungan kedua variable semakin lemah. Besar kecilnya angka korelasi menentukan kuat atau lemahnya hubungan kedua variable. Selain itu, untuk menentukan signifikansi hubungan kedua variable dapat dianalisis dengan menggunakan probabilitas $<0,05$ yang menunjukkan bahwa hubungan kedua variable tesebut signifikan. Selain itu, jika kita ingin mengetahui besarnya sumbangan atau peran variable terhadap perubahan perilaku dapat dihitung dengan rumus koefisien determinasi, $\mathrm{KD}=\mathrm{r}^{2} \mathrm{x} 100 \%$.

Data studi kasus diperoleh dari hasil gabungan tes psikologi dan wawancara 160 orang karyawan baru yang mulai di tahun 2008 (dengan periode awal yang berbeda-beda) dan hasil kinerja di tahun 2009 dari ke 160 orang karyawan tersebut. Hasil gabungan tes psikologi itu terdiri dari 3 kategori, yaitu disarankan, dipertimbangan dan tidak disarankan. Masing-masing memiliki skor 3, 4 dan 5. Sedangkan hasil kinerja, dibagi menjadi 3 kategori, yaitu nilai KPI, nilai kompetensi dan total score. Ketiga nilai ini memiliki range nilai dari 1 sampai dengan 6, dengan nilai tengah 4,5. Total skor sendiri diperoleh dari 70\% nilai KPI dan 30\% nilai kompetensi.

\section{HASIL DAN PEMBAHASAN}

Selama tahun 2008, recruiter dari Yayasan X telah menerima 160 orang karyawan baru untuk posisi yang berbeda-beda dan pada waktu yang berbeda-beda pula. Untuk mendapatkan 160 karyawan baru, Yayasan X telah melakukan seleksi terhadap lebih dari 500 kandidat. Setiap kandidat 
akan melalui tahapan-tahapan yang telah dijelaskan pada bab sebelumnya. Pada akhirnya, User dari Yayasan X harus mengambil keputusan terhadap seleksi berdasarkan semua tahapan tersebut. Jika kita lihat dari hasil tes gabungan antara tes psikologi dan wawancara dari 160 karyawan baru yang diterima menunjukkan bahwa Yayasan X telah mengambil 34 orang yang disarankan, 65 orang yang dipertimbangkan dan 61 orang yang tidak disarankan. Karyawan baru tersebut terdiri dari 54 wanita dan 106 pria serta dengan level Staf 115 orang, level Officer 17 orang, level Senior Officer 20 orang dan level Manager 9 orang.

Tabel 1 Hasil gabungan tes psikologi dan wawancara

\begin{tabular}{llrrrr}
\hline & & & & \multicolumn{2}{c}{ Cumulative } \\
Valid & Tidak disarankan & 61 & 38,1 & 38,1 & 38,1 \\
& Dipertimbangkan & $\mathbf{6 5}$ & $\mathbf{4 0 , 6}$ & $\mathbf{4 0 , 6}$ & $\mathbf{7 8 , 8}$ \\
& Disarankan & 34 & 21,3 & 21,3 & 100,0 \\
& Total & 160 & 100,0 & 100,0 & \\
\hline
\end{tabular}

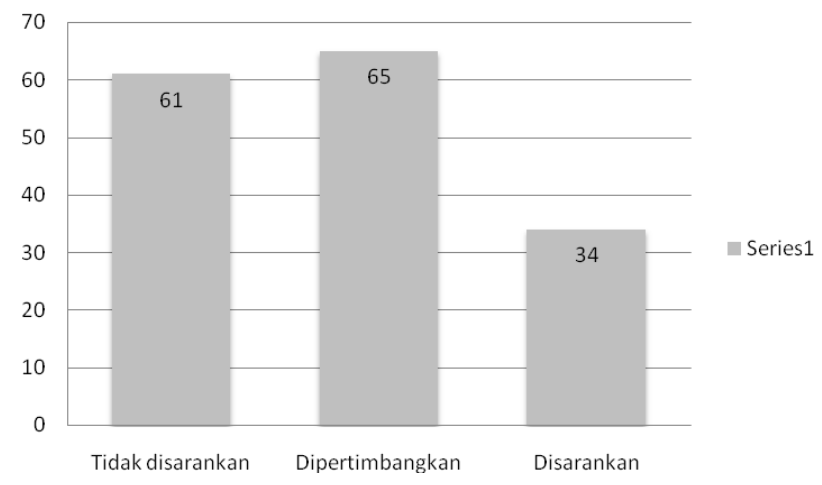

Gambar 4 Hasil gabungan tes psikologi dan wawancara

Terlihat dari tabel 1 dan gambar 4 di atas, Yayasan $\mathrm{X}$ cenderung untuk mengambil orang yang hasil tes gabungannya "dipertimbangkan" yaitu sebanyak 65 orang dari 160 orang yang diterima sebagai karyawan baru. Setelah 160 karyawan baru tersebut diterima, maka Yayasan X akan melakukan training dan development terhadap mereka, dalam bentuk formal maupun informal. Selanjutnya, pada tahun 2009, dengan minimal masa kerja 1 tahun, 160 karyawan tersebut akan mengalami penilaian kinerja pada sekitar bulan Oktober atau Desember.

Hasil penilaian kinerja, akan memberikan 3 (tiga) nilai, yaitu nilai Key Performance Indication (KPI), nilai kompetensi dan nilai total dari KPI dan kompetensi. Dari hasil pernilaian kinerja berdasarkan nilai KPI, didapatkan data sebagai berikut:

Tabel 2 Hasil nilai KPI

\begin{tabular}{llrrrr}
\hline & N & Minimum & Maximum & \multicolumn{1}{c}{ Mean } & Std. Deviation \\
\hline KPI & 160 & 3,23 & 5,96 & 5,0790 &, 51596 \\
Valid N (listwise) & 160 & & & & \\
\hline
\end{tabular}


Tabel 2 menunjukkan bahwa dari 160 karyawan tersebut, nilai KPI terendah adalah 3,23 dan nilai KPI tertinggi adalah 5,96 dengan rata-rata nilai KPI 5,07. Nilai KPI yang kurang baik dengan angka dibawah 4,5 didapatkan oleh 16 orang karyawan, sedangkan sisanya sebanyak 144 orang memiliki nilai KPI diatas 4,5. Sedangkan untuk hasil penilaian berdasarkan kompetensi didapatkan data sebagai berikut:

Tabel 3 Hasil nilai kompetensi

\begin{tabular}{lrrrrr} 
& N & Minimum & Maximum & Mean & Std. Deviation \\
\hline Competencies & 160 & 3,64 & 5,96 & 5,0940 &, 51848 \\
Valid N (listwise) & 160 & & & & \\
\hline
\end{tabular}

Tabel 3 menunjukan bahwa dari 160 karyawan tersebut, nilai kompetensi terendah adalah 3,64 dan nilai kompetensi tertinggi adalah 5,96 dengan rata-rata nilai kompetensi 5,09. Nilai kompetensi yang kurang baik dengan angka dibawah 4,5 didapatkan oleh 20 orang karyawan, sedangkan sisanya sebanyak 140 orang karyawan memiliki nilai kompetensi diatas 4,5. Selanjutnya, total nilai gabungan antara 70\% nilai KPI dan 30\% nilai kompetensi adalah sebagai berikut:

Tabel 4 Hasil gabungan nilai KPI dan competencies

\begin{tabular}{lrrrrr} 
& N & Minimum & Maximum & Mean & Std. Deviation \\
\hline $\begin{array}{l}\text { Total Score 70\% KPI dan } \\
\text { 30\% Competencies }\end{array}$ & 160 & 3,87 & 5,92 & 5,0860 &, 45067 \\
Valid N (listwise) & 160 & & & & \\
\hline
\end{tabular}

Hasil di Tabel 4 menunjukan bahwa dari 160 karyawan tersebut, hasil nilai gabungan (total score) KPI dan kompetensi terendah adalah 3,87 dan tertinggi adalah 5,92 dengan nilai rata-rata 5,086. Hasil gabungan nilai KPI dan kompetensi yang kurang baik dengan angka dibawah 4,5 didapatkan oleh 15 orang karyawan, sedangkan sisanya sebanyak 145 orang karyawan memiliki nilai diatas 4,5.

Dilihat dari semua hasil di atas, ternyata tidak semua karyawan yang nilai KPI nya dibawah angka 4,5 juga memiliki nilai yang kurang baik juga pada nilai kompetensi dan total score. Hanya 8 orang dari 160 orang karyawan yang memiliki nilai yang konsisten dibawah 4,5 pada ketiga nilai KPI, kompetensi dan gabungan nilai KPI dan kompetensi.

Jika diperhatikan, dari 160 orang karyawan tersebut, 61 orang karyawan masuk ke Yayasan $\mathrm{X}$ dengan hasil tes tidak disarankan tetapi hanya 8 orang karyawan yang mendapatkan hasil kinerja yang konsisten rendah dibawah 4,5. Hal ini sudah menunjukkan bahwa tidak ada hubungan antara hasil tes dengan nilai hasil kinerja karyawan dengan masa kerja minimum 1 tahun. Selain itu, menunjukkan juga bahwa ada keberhasilan dari managemen kinerja tersebut, yang terdiri dari motivasi untuk mencapai tujuan, rewards dan harapan dari individu. Faktor lainnya adalah training dan development yang berhasil membantu seseorang untuk meningkatkan hasil kinerjanya.

Untuk memperkuat asumsi di atas, akan dikorelasikan antara hasil kinerja dengan hasil tes yang dilakukan pada seleksi. Pada korelasi pertama antara nilai KPI dan hasil tes, didapat hasil korelasi sebagai berikut: 
Tabel 5 Hasil Korelasi antara nilai KPI dengan hasil tes

\begin{tabular}{llrr}
\hline & & & $\begin{array}{c}\text { Hasil gabungan tes } \\
\text { psikologi dan } \\
\text { wawancara }\end{array}$ \\
\hline KPI & Pearson Correlation & 1 &, 126 \\
& Sig. (2-tailed) & &, 112 \\
& $\mathrm{~N}$ & 160 & 160 \\
$\begin{array}{l}\text { Hasil gabungan tes psikologi } \\
\text { dan wawancara }\end{array}$ & Pearson Correlation &, 126 & 1 \\
& Sig. (2-tailed) &, 112 & 160 \\
\hline
\end{tabular}

Jika dilihat dari hasil penghitungan maka korelasi antara variable nilai KPI dengan hasil tes menunjukkan angka sebesar 0,126. Angka tersebut menunjukan korelasi yang sangat lemah (dianggap tidak ada). Artinya, tidak ada hubungan antara nilai KPI dengan hasil tes. Terlihat juga bahwa angka probabilitas hubungan antara nilai KPI dengan hasil tes ialah sebesar 0,112. Angka probabilitas 0,112 $>0,05$ sehingga bisa dikatakan bahwa hubungan kedua variable tersebut tidak signifikan. Besarnya sumbangan variable hasil tes terhadap hasil kinerja dalam nilai KPI ialah sebesar 1,59\%.

Pada korelasi kedua, dikorelasikan antara nilai kompetensi dengan hasil tes yang dilakukan pada seleksi, dan didapat hasil sebagai berikut:

Tabel 6 Hasil Korelasi antara nilai kompetensi dengan hasil tes

\begin{tabular}{llrr}
\hline & & & $\begin{array}{c}\text { Hasil gabungan tes } \\
\text { psikologi dan } \\
\text { wawancara }\end{array}$ \\
\hline Competencies & Pearson Correlation & Competencies &, 046 \\
& Sig. (2-tailed) & 1 &, 562 \\
& $\mathrm{~N}$ & 160 & 160 \\
$\begin{array}{l}\text { Hasil gabungan tes psikologi } \\
\text { dan wawancara }\end{array}$ & Pearson Correlation &, 046 & 1 \\
& Sig. (2-tailed) &, 562 & 160 \\
\hline
\end{tabular}

Jika dilihat dari hasil penghitungan maka korelasi antara variable nilai kompetensi dengan hasil tes menunjukkan angka sebesar 0,046. Angka tersebut menunjukan korelasi yang sangat lemah (dianggap tidak ada). Artinya, tidak ada hubungan antara nilai KPI dengan hasil tes. Terlihat juga bahwa angka probabilitas hubungan antara nilai KPI dengan hasil tes ialah sebesar 0,562. Angka probabilitas 0,562 > 0,05 sehingga bisa dikatakan bahwa hubungan kedua variable tersebut tidak signifikan. Besarnya sumbangan variable hasil tes terhadap hasil kinerja dalam nilai KPI ialah sebesar $0,216 \%$.

Pada korelasi ketiga, dikorelasikan antara nilai total gabungan 70\% KPI dan 30\% kompetensi dengan hasil tes yang dilakukan pada seleksi, dan didapat hasil sebagai berikut: 
Tabel 7 Hasil Korelasi antara nilai total score KPI dan kompetensi dengan hasil tes

\begin{tabular}{llrr}
\hline & & $\begin{array}{c}\text { Total Score } \\
70 \% \text { KPI dan } \\
30 \%\end{array}$ & $\begin{array}{c}\text { Hasil gabungan } \\
\text { tes psikologi dan } \\
\text { wawancara }\end{array}$ \\
\hline Total Score 70\% KPI dan & Pearson Correlation & 1 &, 113 \\
30\% Competencies & Sig. (2-tailed) & 160 &, 153 \\
& $\mathrm{~N}$ &, 113 & 160 \\
Hasil gabungan tes psikologi & Pearson Correlation &, 153 & 1 \\
dan wawancara & Sig. (2-tailed) & 160 & 160 \\
& $\mathrm{~N}$ & & \\
& & & 160 \\
\hline
\end{tabular}

Jika dilihat dari hasil penghitungan, maka korelasi antara variabel nilai total skor KPI dan kompetensi dengan hasil tes menunjukkan angka sebesar 0,113. Angka tersebut menunjukan korelasi yang sangat lemah (dianggap tidak ada). Artinya, tidak ada hubungan antara nilai KPI dengan hasil tes. Terlihat juga bahwa angka probabilitas hubungan antara nilai KPI dengan hasil tes ialah sebesar 0,153. Angka probabilitas 0,153 > 0,05 sehingga bisa dikatakan bahwa hubungan kedua variable tersebut tidak signifikan. Besarnya sumbangan variable hasil tes terhadap hasil kinerja dalam nilai KPI ialah sebesar 1,28\%. Jika diperhatikan lebih lanjut, semua hasil korelasi antara nilai kinerja dan hasil tes tidak signifikan, hal ini sudah terlihat dari data itu sendiri. Dari semua karyawan yang memiliki hasil tes "disarankan" (34 orang) pada saat seleksi, hanya 1 orang yang memiliki nilai KPI dibawah 4,5 (2,94\%) sedangkan untuk nilai kompetensi dan total score, semua karyawan yang "disarankan" memiliki nilai diatas 4,5. Sedangkan untuk semua karyawan yang memiliki hasil tes “dipertimbangkan" (65 orang) pada saat seleksi, 8 orang memiliki nilai KPI dibawah 4,5 (12,31\%), 12 orang memiliki nilai kompetensi dibawah 4,5 $(18,46 \%)$ dan 8 orang memiliki nilai total score dibawah 4,5 (12,31\%). Untuk karyawan yang memiliki hasil tes "tidak disarankan" (61 orang) pada saat seleksi, hanya 8 orang yang memiliki nilai KPI dibawah 4,5 (13,1\%), 8 orang memiliki nilai kompetensi dibawah 4,5 (13,1\%) dan 7 orang memiliki nilai total score dibawah 4,5 (11,48\%).

\section{SIMPULAN}

Hasil analisa diatas menunjukkan bahwa tidak ada hubungan yang signifikan antara hasil tes gabungan tes psikologi dan wawancara dengan kinerja karyawan baru setelah masa kerja minimum 1 tahun Hasil ini bisa memberikan banyak sekali asumsi mengenai penyebabnya. Penyebab yang pertama adalah, kemungkinan bahwa tes yang digunakan oleh Yayasan $\mathrm{X}$ belum divalidasi dengan baik, terutama dalam hal data yang dihasilkan adalah kualitatif, bukan kuantitatif, sehingga perlu dipikirkan untuk melakukan konversi dari hasil kualitatif menjadi hasil kuantitatif. Yang kedua, skema training dan development yang cukup baik sehingga karyawan yang awalnya pada proses seleksi memiliki nilai "tidak disarankan" dapat mengembangkan diri dengan baik. Ketiga, dukungan dan coaching dari para manager atau supervisor juga membantu karyawan yang awalnya pada proses seleksi memiliki nilai "tidak disarankan" sehingga mereka dapat mencapai tujuan dan visi yang telah ditetapkan oleh perusahaan. Sebagai saran penelitian lanjutan, akan dibuat konversi kualitatif menjadi kuantitatif pada hasil gabungan tes psikologi dan wawancara, sehingga hasil disarankan, dipertimbangkan dan tidak disarankan menjadi lebih bermakna. Selain itu, perlu dilakukan lagi review bagi alat tes psikologi tersebut, terutama yang berhubungan dengan validitasnya. Penelitian lanjutan juga dapat dilakukan untuk melihat keefektifan dari proses training dan development, serta keefektifan dari managemen kinerja. 


\section{DAFTAR PUSTAKA}

Anastasia, A., \& Urbina, S. (1997). Psychological Testing. USA: Simon \& Schuster.

Armstrong, M. (1995). Performance Management. London: Kogan Page.

Compton, R.L., Morrissey, W.J. \& Nankervis, A.R. (2002). Effective Recruitment and Selection Practices, 3rd edn., Australia: CCH Australia Pty Ltd.

Hamilton, C. H. (2008). Communicating for Results: a Guide for Business and the Professions. Thomas Learning Inc., (online), diakses 28 September 2010 dari http://books.google.co.id/books?id=aGc4H89o3tEC\&pg=PA189\&lpg=PA189\&dq=Intervie w+definition+stewart+and+cash

Patton, M. Q. (1990). Qualitative Evaluation and Research Methods. California: SAGE publications.

Roscoe, J. T. (1969). Fundamental Research Statistics: for the behavioral sciences. USA: Holt, Rinehart \& Winston.

Sarwono, J. (2006). Analisa Data Penelitian menggunakan SPSS. Yogyakarta: ANDI.

Schultz, D., \& Schultz, S. A. (2006). Psychology \& Work Today. New Jersey: Pearson.

Shaughnessy, J.J. \& Zechmeister, E.B. (1997). Research methods in psychology. New York: McGrawHill.

Sukadji, S. (2000). Menyusun dan mengevaluasi laporan penelitian. Jakarta: UI-Press.

Syamsuddin, A. (1984). Psikologi 